\title{
LIQUID WATER ABSORPTION IN COATED NORWAY SPRUCE: IMPACT OF HEARTWOOD, SAPWOOD, DENSITY AND WEATHER EXPOSURE
}

\author{
Tinh Sjökvist ${ }^{1, s}$, Åsa Blom ${ }^{1}$, Sheikh Ali Ahmed ${ }^{1}$
}

\begin{abstract}
Water is one of the most significant factors for the durability of wood. A common solution is to use a coating to protect and maintain low water content. However, little knowledge exists how the underlying wood substrate affects the water sorption of coated wood. Therefore, the liquid water absorption of coated and uncoated Norway spruce heartwood and sapwood with a variety of densities was measured by letting the panels float freely in the water. The effect of one year weathering of the coatings was also included. Coated heartwood and sapwood had no difference in water absorption in opposite to uncoated spruce. The influence of heartwood and sapwood seemed to have limited impact when a coating hindered the presence of free water. Wood density had a positive effect on the absorption of coated wood, i.e. low absorption for low-density samples, in opposite to uncoated samples. Low-density characteristic also contributed to a lower increase of water absorption after weather degradation, for samples with water-borne coatings. Natural weathering enhanced the effect of wood characteristics on coated samples, likely by an increase of coating permeability.
\end{abstract} lity

Keywords: Alkyd, acrylic, coating permeability, linseed oil, moisture content, Picea abies, wood durabi-

\section{INTRODUCTION}

The transcendence towards a bio-based economy has increased the interest of tall wood buildings. Sweden is one of the nations who actively strive for multi-family houses made of wood, often in combination with a coated wooden facade. There are however some challenges to reduce the maintenance interval of the façades and prevent degradation.

Water is a major factor in the outdoor performance and durability of wood. A low moisture content (MC) drastically reduces the degradation from deteriorating biological organisms on the wood substrate (Eaton and Hale 1993). The coating has for that reason an important role, as a protecting barrier towards water absorption. However, the understanding of the inherent properties of wood in the overall water absorption behaviour of a coated product is still in its beginning.

Several studies have highlighted the difference in water absorption of different wood characteristics. For example, uncoated heartwood has lower water absorption than sapwood. The lower sorption of heartwood is explained with processes like the irreversible nature of pit aspiration during heartwood formation (Thomas and Kringstad 1971) and the amount and type of extractives deposited in the wood structure (Hillis 1987, Flynn 1995, Sjökvist et al. 2018). Wood density with a variation in voids and morphological structure is another wood attribute that affects the water absorption rate, i.e. high density lowers the absorption rate (Booker and Kininmonth 1978). 
Norway spruce (Picea abies) is the most common species in the Swedish market for coated panels in outdoor applications. Only a few have explored the above-mentioned natural variation specifically for uncoated spruce and even less for coated ones. One of the many reasons could be the inconvenience to separate heartwood and sapwood with their similar physical appearance in the dry state. For uncoated spruce, heartwood has compared to sapwood lower liquid capillary water absorption (Bergström and Blom 2006, Sandberg 2009, Fredriksson and Lindgren 2014). Furthermore, high density contributes to lower void filling and lower liquid absorption rate of water (Sivertsen and Vestøl 2010). The findings lead to the question if coated spruce has similar behaviour.

A coating includes many components. The major components in the formula are the type of resin and solvent. Historically, coating systems have been solvent-borne. However, in the 1960's, the concern of the environment and personal health caused a demand for environmentally friendly solutions like the waterborne systems (Ekstedt 2003). In Sweden, the use of organic solvents is today declining in favour of waterborne systems. One of the remaining solvent-borne systems for the outdoor purpose is the one based on linseed oil resin. Linseed oil has the benefit to come from a renewable resource and creates a very durable paint film due to its continuous curing process (Karlsdotter Lyckman 2005). However, an increasing category of coating formulas for outdoor applications is water-borne systems with two major resin polymers, acrylic or alkyd. These polymers are oil based and can be highly tailor made for the end usage. The possibilities to modify the polymers also leads to a large variety of polymer combinations. The complexity of the polymers has therefore led to intense focus research wise on coatings and less on a wood substrate. Many evaluation of coated products (Ahola et al. 1999, De Meijer and Militz 2001, Ekstedt 2003, Van Meel et al. 2011, Grüll et al. 2013, Lu et al. 2014) have focused on one or a few combinations of wood substrates. For coated Norway spruce there are some studies on different wood characteristics. The studies conclude fewer and shorter cracks on heartwood compared to sapwood (Sandberg 2009) and lower liquid absorption for the fast-grown substrate (Sivertsen and Flæte 2012). The weathering aspect furthermore increases the complex absorption behaviour of a coated wood product, where an aging process changes the barrier properties of the coating (De Meijer 2001, Grüll et al. 2013).

The aim of the study is therefore to investigate details about the absorption behaviour of coated wood for improved product performance in the long run. In this experiment, water absorption of coated spruce heartwood and sapwood with different wood density were considered, the effect of outdoor weathering was also included.

\section{MATERIAL AND METHODS}

\section{Wood material}

Samples made of Norway spruce (Picea abies (L.) Karst.) were selected from two stands in southern Sweden, Växjö. At the time of felling, the wet sapwood border was marked on the logs. The logs were sawn to planks and dried in an industrial kiln at a maximum temperature of $70{ }^{\circ} \mathrm{C}$. The dried $\mathrm{MC}$ of the planks were approximately $17 \%$.

Planed samples free from knots, cracks and resinous streaks were prepared from the plank with dimensions of $(150 \pm 2) \times(70 \pm 2) \times(20 \pm 2) \mathrm{mm}$ (longitudinal $\times$ tangential $\times$ radial). The wood material was after that aclimatized in a climate chamber at $65 \%$ relative humidity $(\mathrm{RH})$ and $20^{\circ} \mathrm{C}$ according to the standard ISO 554 (1976) before treatment and water absorption test.

The density of each replicate was measured after the water absorption test, to avoid any substrate disturbances before the experiment. The density was calculated using a stable oven-dried mass at an oven temperature of $103^{\circ} \mathrm{C}$ with the coating removed. One stand had an oven dry density of $313-370 \mathrm{~kg} / \mathrm{m}^{3}$ (categorised as low-density samples). The other stand had an oven dry density between $450-489 \mathrm{~kg} / \mathrm{m}^{3}$ (categorised as high-density samples). The sample combinations in this study were low-density sapwood (LS), low-density heartwood (LH) and high-density heartwood (HH). Individual oven-dry density for each sample combination is presented in Table 1. High-density sapwood was excluded due to the difficulty to find proper material. 
Table 1: Oven dry density and film thickness of samples with five replicates.

\begin{tabular}{|c|c|c|c|c|c|}
\hline \multicolumn{2}{|c|}{} & \multicolumn{2}{c|}{ Density $\left(\mathbf{k g} / \mathbf{m}^{3}\right)$} & \multicolumn{2}{c|}{ Film thickness $(\boldsymbol{\mu m})$} \\
\hline $\begin{array}{c}\text { Wood } \\
\text { attribute }\end{array}$ & Coating & $\begin{array}{c}\text { Weather } \\
\text { unexposed }\end{array}$ & $\begin{array}{c}\text { Weather } \\
\text { exposed }\end{array}$ & $\begin{array}{c}\text { Weather } \\
\text { unexposed }\end{array}$ & $\begin{array}{c}\text { Weather } \\
\text { exposed }\end{array}$ \\
\hline LS & A & $333(8)$ & $344(24)$ & $151(28)$ & $117(32)$ \\
\hline LH & A & $341(21)$ & $351(30)$ & $151(32)$ & $137(48)$ \\
\hline HH & A & $489(14)$ & $480(13)$ & $142(37)$ & $169(55)$ \\
\hline LS & B & $370(28)$ & $359(25)$ & $137(19)$ & $111(25)$ \\
\hline LH & B & $326(13)$ & $357(27)$ & $133(41)$ & $95(18)$ \\
\hline HH & B & $465(9)$ & $483(32)$ & $96(28)$ & $119(17)$ \\
\hline LS & E & $352(10)$ & $359(40)$ & $191(39)$ & $187(18)$ \\
\hline LH & E & $313(6)$ & $354(27)$ & $160(39)$ & $241(31)$ \\
\hline HH & E & $460(15)$ & $482(27)$ & $172(39)$ & $220(33)$ \\
\hline LS & X & $348(28)$ & $364(50)$ & & \\
\hline LH & X & $322(19)$ & $316(15)$ & & \\
\hline HH & X & $486(38)$ & $450(60)$ & & \\
\hline
\end{tabular}

Values in parenthesis are the standard deviations. LS=Low-density-sapwood, LH=Low-density-heartwood, HH=High-density-heartwood, A=Alkyd, B=Acrylic, E=Linseed oil, $\mathrm{X}=$ Uncoated.

\section{Sample treatment}

Eight equal sets of wood material were selected. Two sets were left uncoated as substrate reference denoted as $\mathrm{X}$ and the six remaining sets were coated. Three film-forming coatings were used, and each coating was applied on two sets of wood material. The coatings had a resin formula made of either alkyd (A), acrylic (B) or linseed oil (E). Alkyd and acrylic formulas were water-borne, whereas the linseed oil formula was solvent-borne. All the coatings were commercially available with no added colour pigments. The coating formulas were unknown except the type of solvent and resin. A brush was used to apply the coatings. Sealing on all areas except the tangential test area was made with two layers of a two-part solvent free epoxy paint (Jotun Antipest Yachting). The remaining uncoated bark side of the tangential surface where after that coated with one layer base coat and two layer top coat of the test coating A, B or E, with at least $2 \mathrm{~mm}$ overlap over the edges. Consequently, the test area exhibits the same size as the sample $(150 \pm 2) \times(70 \pm 2) \mathrm{mm}^{2}$. After painting, all samples were stored in a climate chamber $\left(\mathrm{RH} 65 \%, 20^{\circ} \mathrm{C}\right)$ to reach the equilibrium moisture content. The dry film thickness presented in Table 1, was measured according to the standard (CEN 2007b) chapter 5.4.5.1.2 conical bore with a cutting angle of $\alpha=45^{\circ}$. The average dry film thickness (standard deviation in parenthesis) for the paint systems is $A=144$ (17) $\mu \mathrm{m}, \mathrm{B}=115$ (19) $\mu \mathrm{m}$ and $\mathrm{E}=195$ (26) $\mu \mathrm{m}$. Cracks and other damages on the paint film where observed using a light microscope with a 50 times magnification.

The acclimatised coated and uncoated samples were after that divided into two equal parts, each part consisted of four sets with three coated and one uncoated set of wood material. One part was subjected to natural weather exposure for one year before the liquid water absorption test, and the other part was tested immediately for water absorption. The weather exposure was at Asa field research station, $40 \mathrm{~km}$ north of Växjö, Sweden. Samples were hung on racks at a $45^{\circ}$ inclination in a south direction at approx. $60 \mathrm{~cm}$ above the ground. Five replicates of each combination of wood material and sample treatment were prepared for the water absorption test.

\section{Test method}

Liquid water absorption can be studied in several ways, but there is one explicit method in Europe for coated wood. The standard (CEN 2007a) is an established method to assess the liquid water absorption of coated wood panels (De Meijer 2002, Ekstedt 2002, Metsä-Kortelainen et al. 2006, Sivertsen and Flaete 2012). Coated and sealed panels exhibit a floating test in water, and the amount of water absorbed through the coating is measured under controlled conditions. The use of CEN 2007a to evaluate wood characteristics could, however, need an extension of the soaking time since Sivertsen and Faete (2012) reported a need to prolong the water exposure to four weeks $(672 \mathrm{~h})$ or more to see a significant effect of density on the water absorption of coated spruce.

This study was inspired by standard (CEN 2007a) and followed it in major parts except for two steps. This study had a prolonged water absorption period from the stipulated $72 \mathrm{~h}$ by the standard to $3024 \mathrm{~h}$ (18 weeks). This study did neither follow the in-standard instruction of artificial pre-leaching for any of the samples. The 
artificial pre-leaching procedure consists of a twice-repeated cycle of $24 \mathrm{~h}$ floating face down in deionised water, three hours drying at $20^{\circ} \mathrm{C}$ and $65 \% \mathrm{RH}$, followed by three hours drying at $50^{\circ} \mathrm{C}$ and finally $18 \mathrm{~h}$ drying at $20^{\circ} \mathrm{C}$ and $65 \% \mathrm{RH}$. The pre-leaching procedure is intended to wash out possible surfactants that might affect the water uptake while comparing different coating performances. However, all samples in this study were to be compared within their own coating system with a focus on the variation in wood characteristics. Hence, the pre-leaching procedure was excluded. This study had in addition a complementary sample series with natural weather exposure instead of the artificial pre-leaching procedure. Furthermore, the pre-leaching process could also be too mild and cause no differences in water absorption (Ekstedt and Östberg 2001).

The absorption test was made by letting the samples float freely, but not fully submerged in deionised water with the test surface facing downwards. The surface was ensured to be fully wetted by immersing the sample in an angle to the water. The long edge of the sample was immersed first into the water. The water absorption of the samples was recorded on a scale to the nearest accuracy of $0,01 \mathrm{~g}$ before and after a soaking time of $0,5 \mathrm{~h}, 1 \mathrm{~h}, 2 \mathrm{~h}, 4 \mathrm{~h}, 8 \mathrm{~h}, 24 \mathrm{~h}$ and after that every day during the first week and then every week up to 18 weeks. Excess water on the sample surfaces was gently wiped off with a paper towel before the mass was recorded. The whole procedure was made in a climate chamber $\left(65 \% \mathrm{RH}\right.$ and $\left.20^{\circ} \mathrm{C}\right)$. The water absorption levels at three soaking times $(72 \mathrm{~h}, 672 \mathrm{~h}$ and $3024 \mathrm{~h})$ are presented in the results. The three occasions were selected for the following reasons. The time $72 \mathrm{~h}$ is the required soaking time according to the standard CEN 2007a. The second time range of $672 \mathrm{~h}$ was the shortest period where previous researchers (Sivertsen and Faete 2012) saw an effect from wood type, and the final period $3024 \mathrm{~h}$ was the time where the same researchers (Sivertsen and Faete 2012) reached a similar moisture content (MC) for two samples with different density.

The water absorption of the sample according to the standard (CEN 2007a) is described as the increase in mass in grams per test area. The water absorption for each sample $\left(\Delta \mathrm{m}_{\mathrm{n}}\right)$ was calculated according to Equation 1.

$$
\Delta m_{n}=\left(\frac{m_{n}-m_{i}}{A_{n}}\right) \quad n=1,2,3, \ldots, a
$$

Where $\mathrm{m}_{\mathrm{n}}$ is the recorded mass ( $\mathrm{g}$ ) of the sample $n, m_{i}$ is the initial mass $(\mathrm{g})$ of sample $n$ before the samples were submerged into water, $A_{n}$ is the test area $\left(\mathrm{m}^{2}\right)$ and $a$, is the total number of samples.

Another unit to quantify water sorption is in term of the MC in the sample. The term MC is sometimes more favourable to use compared to mass gain $\left(\mathrm{g} / \mathrm{m}^{2}\right)$ in the aspect of wood durability, giving the living conditions for biological organisms. The MC of the samples is calculated as the percentage water uptake of the sample relative to the oven-dry mass. In this work, water absorption results are presented both as mass gain $(\mathrm{g} /$ $\left.\mathrm{m}^{2}\right)$ in Table 2 and as MC (\%) in Table 3.

Table 2: Water absorption $\left(\mathrm{g} / \mathrm{m}^{2}\right)$ in different samples.

\begin{tabular}{|l|l|l|c|c|c|c|c|}
\hline \multicolumn{2}{|c|}{} & \multicolumn{3}{c|}{$\begin{array}{c}\text { Water absorption } \\
\text { weather unexposed } \\
\left(\mathrm{g} / \mathrm{m}^{2}\right)\end{array}$} & \multicolumn{3}{c|}{$\begin{array}{c}\text { Water absorption } \\
\text { weather exposed } \\
\left(\mathrm{g} / \mathrm{m}^{2}\right)\end{array}$} \\
\hline $\begin{array}{c}\text { Wood } \\
\text { attribute }\end{array}$ & Coating & $\begin{array}{c}72 \\
\text { hours } \\
\text { hours }\end{array}$ & $\begin{array}{c}3024 \\
\text { hours } \\
\text { hours }\end{array}$ & $\begin{array}{c}72 \\
\text { hours }\end{array}$ & $\begin{array}{c}3024 \\
\text { hours }\end{array}$ \\
\hline LS & A & $147(7)$ & $647(18)$ & $960(51)$ & $712(320)$ & $1818(785)$ & $3609(1859)$ \\
\hline LH & A & $167(33)$ & $710(64)$ & $1076(116)$ & $241(99)$ & $889(355)$ & $1801(921)$ \\
\hline HH & A & $150(28)$ & $768(113)$ & $1135(173)$ & $774(448)$ & $2182(860)$ & $3810(1261)$ \\
\hline LS & B & $227(14)$ & $782(68)$ & $929(65)$ & $196(212)$ & $662(247)$ & $994(188)$ \\
\hline LH & B & $239(7)$ & $788(78)$ & $933(149)$ & $141(34)$ & $689(149)$ & $1109(219)$ \\
\hline HH & B & $261(65)$ & $890(34)$ & $1089(62)$ & $574(243)$ & $1840(613)$ & $3027(1042)$ \\
\hline LS & E & $132(48)$ & $492(121)$ & $879(38)$ & $48(8)$ & $305(46)$ & $904(56)$ \\
\hline LH & E & $98(23)$ & $405(73)$ & $782(111)$ & $48(9)$ & $323(62)$ & $932(147)$ \\
\hline HH & E & $136(52)$ & $494(64)$ & $931(77)$ & $134(65)$ & $511(129)$ & $1025(132)$ \\
\hline LS & X & $1032(113)$ & $2484(388)$ & $4650(2898)$ & $1329(203)$ & $3415(619)$ & $5988(962)$ \\
\hline LH & X & $995(113)$ & $2645(518)$ & $4066(1249)$ & $1243(163)$ & $2941(322)$ & $5315(588)$ \\
\hline HH & X & $865(62)$ & $2003(315)$ & $2406(678)$ & $1275(165)$ & $3169(516)$ & $5352(1024)$ \\
\hline
\end{tabular}

Values in parenthesis are the standard deviations. LS=Low-density-sapwood, LH=Low-density-heartwood, HH=High-density-heartwood, A=Alkyd, B=Acrylic, E=Linseed oil, $\mathrm{X}=$ uncoated. 
Table 3: Moisture content (MC) in different samples.

\begin{tabular}{|c|c|c|c|c|c|c|c|c|}
\hline \multicolumn{2}{|c|}{} & $\begin{array}{c}\text { Initial MC } \\
(\%)\end{array}$ & \multicolumn{3}{|c|}{$\begin{array}{c}\text { MC } \\
\text { weather unexposed } \\
(\%)\end{array}$} & \multicolumn{3}{|c|}{$\begin{array}{c}\text { MC } \\
\text { weather exposed } \\
(\%)\end{array}$} \\
\hline $\begin{array}{c}\text { Wood } \\
\text { attribute }\end{array}$ & Coating & $\begin{array}{c}0 \\
\text { hours }\end{array}$ & $\begin{array}{c}72 \\
\text { hours }\end{array}$ & $\begin{array}{c}672 \\
\text { hours }\end{array}$ & $\begin{array}{c}3024 \\
\text { hours }\end{array}$ & $\begin{array}{c}72 \\
\text { hours }\end{array}$ & $\begin{array}{c}672 \\
\text { hours }\end{array}$ & $\begin{array}{c}3024 \\
\text { hours }\end{array}$ \\
\hline LS & A & $11,8(0,1)$ & $14(0,2)$ & $21,8(0,2)$ & $26,7(1,1)$ & $22,4(4,5)$ & $38,7(11,0)$ & $65,1(26,1)$ \\
\hline LH & A & $11,8(0,1)$ & $14,4(0,6)$ & $22,8(1,2)$ & $28,5(2,0)$ & $15,5(1,3)$ & $25,0(4,6)$ & $38,2(12,2)$ \\
\hline HH & A & $11,7(0,2)$ & $13,3(0,3)$ & $20,3(1,4)$ & $24,4(2,2)$ & $20,7(4,6)$ & $37,0(8,5)$ & $55,9(12,2)$ \\
\hline LS & B & $11,9(0,3)$ & $15,1(0,5)$ & $23,2(1,1)$ & $25,4(1,3)$ & $14,8(2,6)$ & $21,7(2,8)$ & $26,5(1,8)$ \\
\hline LH & B & $11,8(0,1)$ & $15,6(0,3)$ & $24,3(0,8)$ & $26,6(2,0)$ & $13,9(0,5)$ & $21,9(1,7)$ & $27,9(2,2)$ \\
\hline HH & B & $11,8(0,1)$ & $14,8(0,8)$ & $22,4(0,3)$ & $24,8(1,0)$ & $18,4(2,7)$ & $32,9(6,7)$ & $46,4(11,5)$ \\
\hline LS & E & $11,8(0,2)$ & $13,7(0,7)$ & $18,9(1,7)$ & $24,6(0,5)$ & $12,6(0,2)$ & $16,2(0,6)$ & $24,6(0,6)$ \\
\hline LH & E & $12,0(0,1)$ & $13,5(0,2)$ & $18,3(1,0)$ & $24,3(1,4)$ & $12,7(0,1)$ & $16,7(0,7)$ & $25,4(1,1)$ \\
\hline HH & E & $11,7(0,1)$ & $14,5(2,7)$ & $18,8(3,2)$ & $24(3,5)$ & $13,3(0,7)$ & $17,4(1,2)$ & $23,3(1,8)$ \\
\hline LS & X & $11,9(0,1)$ & $28,4(1,9)$ & $51,2(3,2)$ & $83,5(37,2)$ & $31,4(3,0)$ & $61,9(8,1)$ & $99,7(13,7)$ \\
\hline LH & X & $12,1(0,2)$ & $28,8(2,2)$ & $56,7(10,7)$ & $81(24,8)$ & $32,8(2,8)$ & $61,1(5,8)$ & $100,9(13,6)$ \\
\hline HH & X & $11,9(11,9)$ & $22,4(0,9)$ & $36,3(4,3)$ & $41,3(9,4)$ & $27,8(2,1)$ & $51,3(6,1)$ & $78,6(14,0)$ \\
\hline
\end{tabular}

Values in parenthesis are the standard deviations. LS=Low-density-sapwood, LH=Low-density-heartwood, HH=High-density-heartwood, $\mathrm{A}=$ Alkyd, $\mathrm{B}=$ Acrylic, $\mathrm{E}=$ Linseed oil, $\mathrm{X}=$ uncoated.

\section{Statistical analysis}

The water absorption quantified as mass gain were analysed using a Student's t-test with the software program Matlab (R2013b), considering a single factor experiment with a normal distribution. The test analysed the water absorption for two conditions, between low-density sapwood and heartwood and between low- and high-density heartwood.

\section{RESULTS AND DISCUSSION}

No visual cracks and damages on the coating surfaces were seen after one year weather exposure without microscope assistance. Evaluation of the surfaces through a microscope with a 50 times magnification (Figure 1) revealed that the weather-exposed alkyd coating (A) had small wrinkles while the fresh unexposed coating had a smoother surface. The exposed acrylic coating (B) had some more corroded surface compared to the samples without weather exposure. Samples with linseed oil paint (E) changed from a rough and uneven surface to a smoother and uniform surface after weather exposure. Water absorption curves for all samples are illustrated in Figure 2. The higher MC for weather-exposed samples indicated an increase coating permeability, probably induced by a degradation of the coating. The indicated higher permeability can also be seen in Table 2 and Table 3 with higher water sorption both as mass gain $\left(\mathrm{g} / \mathrm{m}^{2}\right)$ and as MC (\%) respectively.
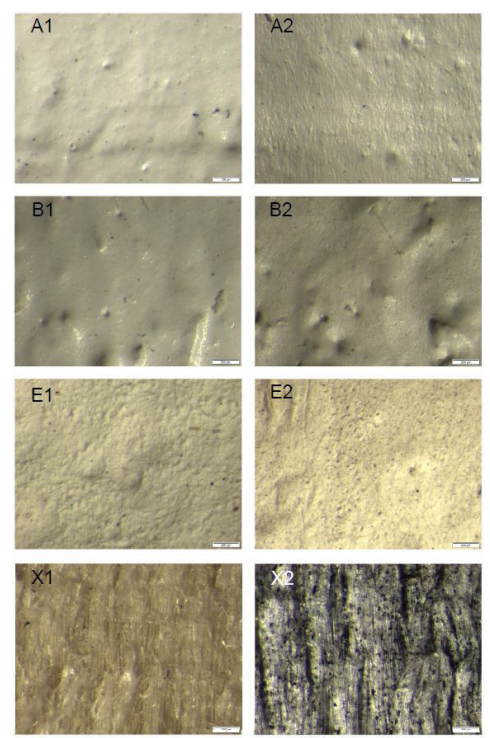

Figure 1: Visual appearance of the coating at 50 times magnification. $1=$ no weathering and $2=$ with one year of outdoor exposure, $\mathrm{A}=\mathrm{Alkyd}, \mathrm{B}=$ Acrylic, $\mathrm{E}=$ Linseed oil, $\mathrm{X}=$ uncoated.

The scale in the lower right corner $=200 \mu \mathrm{m}$. 

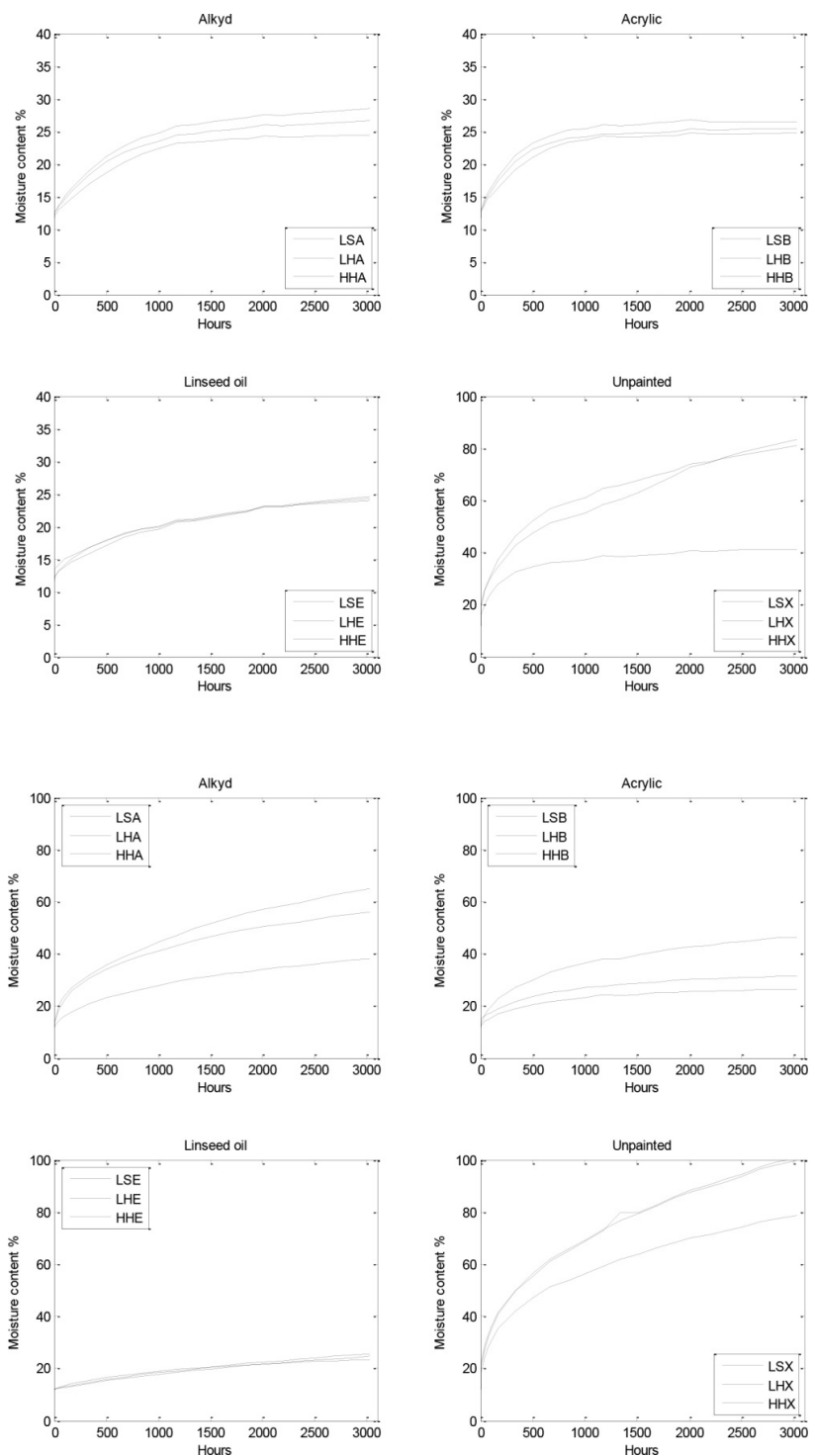

Figure 2: Moisture content increase during a liquid water soaking time up to $3024 \mathrm{~h}$. The four upper graphs are weather unexposed samples and the four lower graphs are weather exposed samples.

LS=Low-density-sapwood, LH=Low-density-heartwood, HH=High-density-heartwood, A=Alkyd, B=Acrylic, E=Linseed oil, X=uncoated. Note the different scale of y-axis on sample X.

Table 4 continues to analyse the statistical probability for a different mass water uptake $\left(\mathrm{g} / \mathrm{m}^{2}\right)$ between low-density heart- and sapwood samples. There was a difference in water absorption, but for a majority of the samples, the difference was not statistically significant due to the large deviation in sorption levels within the replicates (Table 4). The weather-exposed samples coated with alkyd paint system (A) was the only samples with a significantly higher uptake for sapwood samples, including both coated and uncoated samples. Also, the significant difference was only valid up to 672 hours of soaking time. The indifference in absorption for uncoated samples is hard to explain since previously published work on uncoated spruce heartwood and sapwood showed different transversal absorption (Bergström and Blom 2006, Metsä-Kortelainen et al. 2006). One explanation behind the higher uptake for uncoated spruce sapwood is the capacity of surface-active extractives to lower the water surface tension and hence increase the absorption rate (Sjökvist et al. 2018). The indifference in water absorption between coated heartwood and sapwood indicated however, that wood extractives might have no impact when a coating hinders free water to enter the wood structure. 
Table 4: Probability value (P-value) of low-density sapwood and heartwood in water absorption $\left(\mathrm{g} / \mathrm{m}^{2}\right)$ test.

\begin{tabular}{|l|l|l|l|l|l|l|}
\hline & \multicolumn{2}{|c|}{72 h } & \multicolumn{2}{c|}{$672 \mathrm{~h}$} & \multicolumn{2}{c|}{3024 } \\
\hline & Unexposed & Exposed & Unexposed & Exposed & Unexposed & Exposed \\
\hline Coating type & \multicolumn{5}{|c|}{ P-value } \\
\hline Alkyd (A) & 0,2129 & $0,0138^{*}$ & 0,066 & $0,0425^{*}$ & 0,0766 & 0,0828 \\
\hline Acrylic (B) & 0,1079 & 0,5852 & 0,8985 & 0,8401 & 0,9533 & 0,3411 \\
\hline Linseed oil (E) & 0,1903 & 0,9733 & 0,2049 & 0,615 & 0,1011 & 0,5979 \\
\hline Uncoated (X) & 0,6194 & 0,4844 & 0,5927 & 0,1668 & 0,6899 & 0,196 \\
\hline
\end{tabular}

* Significant difference at the 0,05 level.

For a weather-exposed coating, on the other hand, a degraded paint film might develop cracks. Coating A which had small wrinkles on the weathered surface showed initial film degradation with potential microcracks and increased coating permeability. The higher coating permeability was seen through the higher water absorption in Table 2. The group of weathered sapwood replicates with coating A and a density around $350 \mathrm{~kg} /$ $\mathrm{m}^{3}$ (Figure 3$)$ had a tendency of higher MC (max 100\%) than the ones made of weathered heartwood $(\max \mathrm{MC}$ $52 \%$ ). It seems like the water absorption behaviour of coated heartwood and sapwood transcends to behave more like uncoated along with the increase of coating permeability.

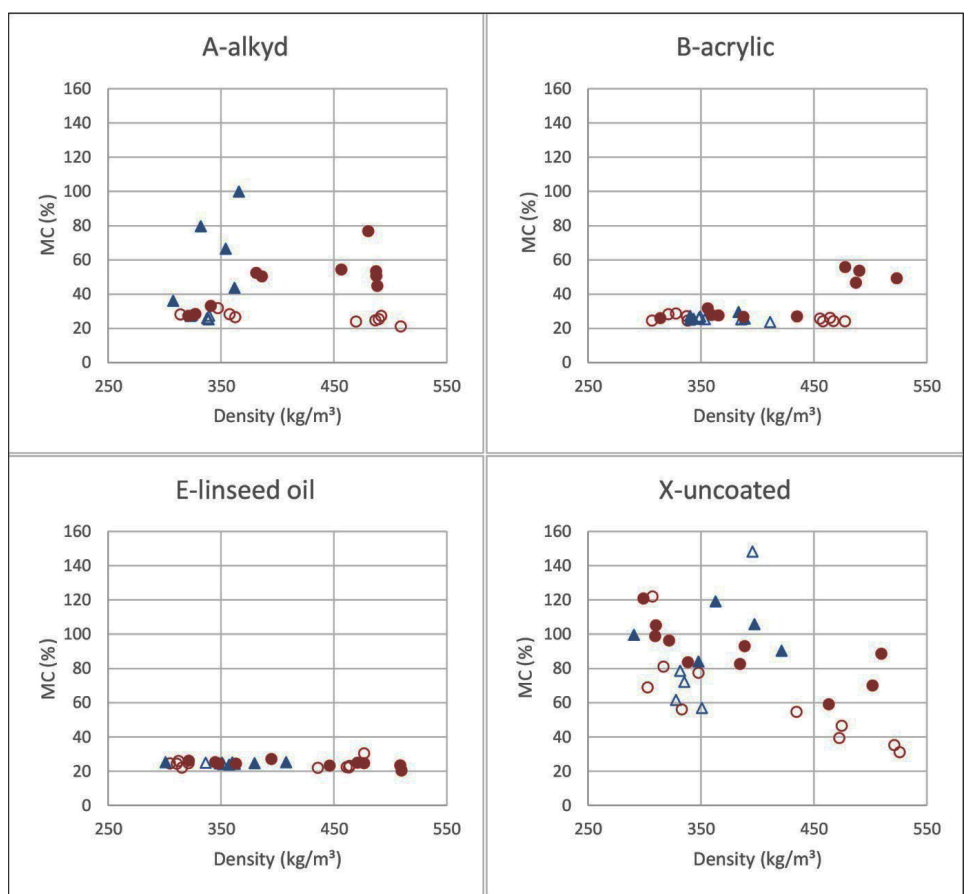

Figure 3: Final $\mathrm{MC}$ after 3024h soaking time for coating $\mathrm{A}, \mathrm{B}$ and $\mathrm{E}$ and uncoated $\mathrm{X}$ relative the individual density of the replicate.

$\boldsymbol{\Delta}$ = sapwood weather exposed, $\Delta=$ sapwood weather unexposed, $\bullet=$ heartwood weather exposed, $\circ=$ heartwood weather unexposed. 
Moving to the water absorption values of high- or low-density heartwood samples in Table 2 and Table 3 , a lower uptake were seen for weathered low-density samples when they were coated and for unweathered high-density samples when they were uncoated. The t-test in Table 5 confirms the different mass water uptake. The coated and weather exposed high-density samples had all except one sample significant higher absorption. The exception was for the samples coated with linseed oil paint (E) at the soaking time of $3024 \mathrm{~h}$. The established knowledge that low-density wood absorbs a higher amount of water does not seems valid for coated wood. In contrary, the result of this work supports the previous finding (Sivertsen and Flæte 2012) that low-density wood has a lower liquid water uptake when coated. The resin polymer seems to interact with the wood structure and sorption chemistry in a complex manner with a more complicated relationship between wood density and MC. The water absorption in relation to wood density is also visualised in Figure 3. The uncoated replicates showed linearity in final MC relative the individual density of each replicate, i.e. high density corresponds to low MC. A similar trend for coated samples was harder to see.

Table 5: Probability value (P-value) of high- and low-density heartwood in water absorption $\left(\mathrm{g} / \mathrm{m}^{2}\right)$ test.

\begin{tabular}{|l|l|l|l|l|l|l|}
\hline & \multicolumn{2}{|c|}{72 h } & \multicolumn{2}{c|}{ 672h } & \multicolumn{2}{c|}{ 3024 h } \\
\hline & Unexposed & Exposed & Unexposed & Exposed & Unexposed & Exposed \\
\hline Coating type & \multicolumn{5}{|c|}{ P-value } \\
\hline Alkyd (A) & 0,4132 & $0,0319^{*}$ & 0,3438 & $0,0146^{*}$ & 0,5400 & $0,0181^{*}$ \\
\hline Acrylic (B) & 0,473 & $0,0043^{*}$ & $0,0285^{*}$ & $0,0035^{*}$ & 0,0631 & $0,0038^{*}$ \\
\hline Linseed oil (E) & 0,2021 & $0,0189^{*}$ & 0,1554 & $0,0189^{*}$ & 0,1116 & 0,2042 \\
\hline Uncoated (X) & 0,0544 & 0,7658 & $0,0452^{*}$ & 0,4261 & $0,0311^{*}$ & 0,9019 \\
\hline
\end{tabular}

* Significant difference at the 0,05 level.

Figure 4 shows the increase in coating permeability with weather exposure. The increase in water absorption was higher for high-density heartwood samples when uncoated or coated with a water-borne coating. The low-density heartwood had in comparison a lower absorption increase. The results indicate that the porosity of the wood structure interacts with the barrier properties of a coating in an unexpected way (Table 1). A general conception in Sweden is that slow-grown, low porous heartwood is preferable to use in outdoor applications. The numbers in Figure 4 suggests the opposite. One hypothesis could be the larger polymer size of water-borne coatings compared to solvent-borne coatings. Larger polymers need bigger cavities for penetration and anchoring in the wood substrate. Hence, the interaction and the durability in the boundary layer between wood and coating might depend on the specific combination of wood and coating properties. The absorption behaviour for samples with water-borne linseed oil coating (E) seemed however unaffected by the wood characteristics. The absorption differences were very low or even negative after weather exposure. The negative values might be related to the replicate selection with a slight unevenness in density distribution between the groups. The lower absorption for coating (E), compared to other coatings might also be due to the ongoing curing that is typical for this type of resin. It might also be due to the influence of higher coating thickness (Table 1). De Meijer and Militz (2001) suggested the importance of film thickness as an impact on the water sorption, where a thicker paint film had a greater barrier effect. 


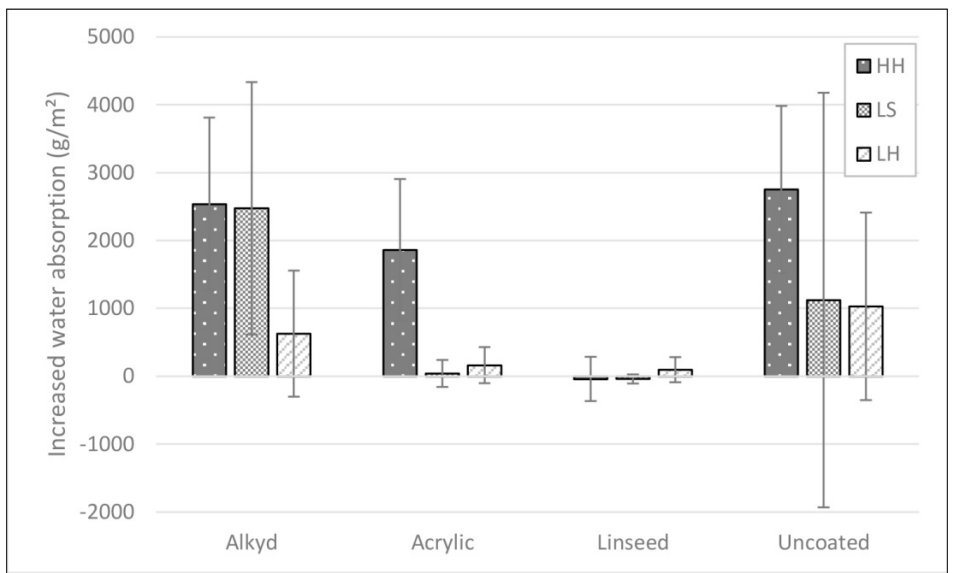

Figure 4: The increased water absorption for samples with weather exposure relative samples without exposure.

Verticle bars represent the standard deviations. HH=high-density heartwood, LS=low-density sapwood, LH=low-density heartwood.

A variety of coating systems was chosen to illustrate a broader effect of wood characteristics on water absorption for coated wood. However, the formulas used are only an example and not representative of the type of resins. There was no intention to compare the sorption levels between different coating systems. In fact, previous results have shown differences in permeability with the same polymer resin depending on other additives in the formula (Ekstedt 2003). The exact composition of each coating formula is also unknown, but the purpose in exploring the effect of wood characteristics on a coated panel is possible as long as the comparison is made strictly within each coating system.

The water sorption is expressed in two different ways in this study, $\mathrm{kg} / \mathrm{m}^{2}$ (Table 2) and \% MC (Table $3)$. Water sorption, especially in the context of outdoor durability is normally expressed as MC since a level between 20-50 \% seems to be most vulnerable to the colonisation of different deteriorating biological organisms (Kollmann and Côté 1968). The test of liquid permeability through a paint film is however according to standard (CEN 2007a) expressed in the units of $\mathrm{kg} / \mathrm{m}^{2}$. The differences in these two ways to express water sorption are noticeable when there is a large variety of density among the tested material. For example, among the weather-exposed uncoated samples, the group made of high-density heartwood had a similar amount of water absorption as the corresponding low-density samples, (HHX $=5352 \mathrm{~kg} / \mathrm{m}^{2}, \mathrm{LHX}=5315 \mathrm{~kg} / \mathrm{m}^{2}$, Table 2 , 3024 h). Same samples had a difference in MC (HHX=78,6 \%, LHX=100,9 \% Table 3) due to the effect of the dry mass in the calculations. The unit $\mathrm{kg} / \mathrm{m}^{2}$ might be more suitable when discussing water sorption in the context of different wood characteristics, especially when comparing the effect from wood density, but MC is still relevant whenever durability of the wood substrate is in focus.

A prolonged water exposure with a soaking time up to $3024 \mathrm{~h}$ was used in comparison to the standard of $72 \mathrm{~h}$. The increased soaking time to $3024 \mathrm{~h}$ gave a larger deviation in absorption levels $\left(\mathrm{g} / \mathrm{m}^{2}\right)$ between the samples. There was, however, no distinct changes of the P-value, which depicts the statistical probability for two samples to have similar levels. Sivertsen and Faete (2012) needed a soaking time of at least $627 \mathrm{~h}$ to detect a difference in water absorption related to different wood characteristics. The samples in this work needed a shorter time. The length of soaking time for detectable absorption character seems, therefore, be related to the choice of coating. 


\section{CONCLUSIONS}

Density but not heartwood and sapwood characteristics affected the water absorption of coated spruce. Heartwood and sapwood samples had a similar water uptake during the completely soaking period except for the initial absorption of samples with an alkyd coating. The results indicated that a coating might hinder wood extractives to affect the water absorption.

Regarding the effect of density, a difference in absorption was present for weathered samples while coated and for unweathered while uncoated. For coated samples, low-density wood had the lowest amount of water absorption. Furthermore had low-density wood an indication of less increase in coating permeability after weathering. The pattern might be related to the interaction between polymer and lumen size.

For uncoated spruce, lowest water absorption was seen for high-density wood. The different behaviour for coated and uncoated spruce is most likely caused by a multi-factor change of surface properties during the weathering.

Weathering increased the water absorption before any visual signs of checks or cracks on the coating were developed. Furthermore, the water absorption transcends to behave more like uncoated spruce along with the increase of coating permeability.

A prolonged soaking time from $72 \mathrm{~h}$ to $3024 \mathrm{~h}$ resulted in a larger divergence in absorption levels among the weathered samples. The increased water absorption did however not lead to a major change in statistic probability for different water absorption behaviour.

\section{ACKNOWLEDGEMENTS}

The authors wish to thank The Bridge, a multidisciplinary research and education collaboration between Linnaeus University and IKEA who have financed this work. We also thank SVEFF, The Swedish Paint and Printing Ink Makers Association, who supported this project. This experiment has also been possible thanks to Swedish Infrastructure of Ecosystem Science (SITES), in this case at Asa field research station.

\section{REFERENCES}

Ahola, P.; Derbyshire, H.; Hora, G.; De Meijer, M. 1999. Water protection of wooden window joinery painted with low organic solvent content paints with known composition. Part 1. Results of inter-laboratory tests. Holz als Roh- und Werkstoff 57 (1): 45-50. https://doi.org/10.1007/PL00002620

Bergström, M.; Blom, Å. 2006. Differences in properties between Norway spruce (Picea abies) heartwood and sapwood. Part 2. Vapour and Liquid permeability. Wood protection Conference. Forest Products Society: New Orleans, USA.

Booker, R.; Kininmonth, J. 1978. Variation in longitudinal permeability of green radiata pine wood. New Zealand Journal of Forestry Science 8 (2): 295-308.

De Meijer, M. 2001. Review: Review on the durability of exterior wood coatings with reduced VOC-content. Progress in Organic Coatings 43: 217-225. https://doi.org/10.1016/S0300-9440(01)00170-9

De Meijer, M. 2002. Comparison between laboratory water permeability tests and wood moisture content of full-scale window frames. Surface Coatings International 85 (2): 131-137. https://doi.org/10.1007/ BF02699753 
De Meijer, M.; Militz, H. 2001. Moisture transport in coated wood. Part 2: Influence of coating type, film thickness, wood species, temperature and moisture gradient on kinetics of sorption and dimensional change. Holz als Roh- und Werkstoff 58 (6): 467-475. https://doi.org/10.1007/s001070050461

Eaton, R.A.; Hale, M.D.C. 1993. Wood: Decay, Pests, and Protection. Chapman \& Hall.

Ekstedt, J. 2002. Studies on the barrier properties of exterior wood coatings. Doctoral Doctoral Thesis, KTH Royal Institute of Technology, Sweden.

Ekstedt, J. 2003. Influence of coating system composition on moisture dynamic performance of coated wood. Journal of Coatings Technology 75 (938): 27-37. https://doi.org/10.1007/BF02697719

Ekstedt, J.; Östberg, G. 2001. Liquid water permeability of exterior wood coatings-testing according to a proposed European standard method. Journal of Coatings Technology 73 (914): 53-59. https://doi.org/10.1007/ BF02698438

European Committee for Standardization. CEN. 2007a. Paint and varnishes - Coating materials and coating systems for exterior wood - Part 5: Assessment of the liquid water permeability, EN 927-5:2007 European Committee for Standardization.

European Committee for Standardization. CEN. 2007b. Paints and varnishes - Determination of film thickness, EN ISO 2808:2007, European Committee for Standardization.

Flynn, K.A. 1995. A review of the permeability, fluid flow, and anatomy of spruce (Picea spp.). Wood and Fiber Science 27 (3): 278-284.

Fredriksson, M.; Lindgren, O. 2014. End grain water absorption and redistribution in slow-grown and fast-grown Norway spruce (Picea abies (L.) Karst.) heartwood and sapwood. Wood Material Science and Engineering 8 (4): 245-252. https://doi.org/10.1080/17480272.2013.847492

Grüll, G.; Truskaller, M.; Podgorski, L.; Bollmus, S.; De Windt, I.; Suttie, E. 2013. Moisture Conditions in Coated wood Panels During 24 Months Natural Weathering at five Sites in Europe. Wood Material Science and Engineering 8 (2): 95-110. https://doi.org/10.1080/17480272.2013.771212

Hillis, W.E. 1987. Heartwood and tree exudates. Springer-Verlag: Berlin.

International Organization for Standardization. ISO. 1976. Standard atmospheres for conditioning and/or testing, ISO 554:1976.

Karlsdotter-Lyckman, K. 2005. Historiska oljefärger i arkitektur och restaurering. Doctoral thesis, Kungliga tekniska högskolan, Sweden.

Kollmann, F.F.P.; Côté, W.A. 1968. Principles of wood science and technology. Springer-Verlag.

Lu, Y.; Xiao, S.; Gao, R.; Li, J.; Sun, Q. 2014. Improved weathering performance and wettability of wood protected by $\mathrm{CeO} 2$ coating deposited onto the surface. Holzforschung 68 (3): 345-351. https://doi. org/10.1515/hf-2013-0119

Metsä-Kortelainen, S.; Antikainen, T.; Viitaniemi, P. 2006. The water absorption of sapwood and heartwood of Scots pine and Norway spruce heat-treated at $170^{\circ} \mathrm{C}, 190^{\circ} \mathrm{C}, 210^{\circ} \mathrm{C}$ and $230^{\circ} \mathrm{C}$. European Journal of Wood and Wood Products 64 (3): 192-197. https://doi.org/10.1007/s00107-005-0063-y

Sandberg, K. 2009. Norway spruce heartwood: properties related to outdoor use. Doctoral thesis, Luleå tekniska universitet, Sweden.

Sivertsen, M.S.; Flaete, P.O. 2012. Water absorption in coated Norway spruce (Picea abies) cladding boards. European Journal of Wood and Wood Products 70 (1-3): 307-317. https://doi.org/10.1007/s00107011-0557-8

Sivertsen, M.S.;Vestøl, G. I. 2010. Liquid water absorption in uncoated Norway spruce (Picea abies) claddings as affected by origin and wood properties. Wood Material Science and Engineering 5 (3): 181-193. 
https://doi.org/10.1080/17480272.2010.503939

Sjökvist, T.; Wålinder, M.E.P.; Blom, Å. 2018. Liquid sorption characterisation of Norway spruce heartwood and sapwood using a multicycle Wilhelmy plate method. International Wood Products Journal 9(2): 58-65. https://doi.org/10.1080/20426445.2018.1467602

Thomas, R.J.; Kringstad, K.P. 1971. The Role of Hydrogen Bonding in Pit Aspiration. Holzforschung 25 (5): 143-149. https://doi.org/10.1515/hfsg.1971.25.5.143

Van Meel, P.A.; Erich, S.J.F.; Huinink, H.P.; Kopinga, K.; De Jong, J.; Adan, O.C.G. 2011. Moisture transport in coated wood. Progress in Organic Coatings 72 (4): 686-694. https://doi.org/10.1016/j.porgcoat.2011.07.011 